ORIGINAL ARTICLE

\title{
Value of serum prolactin in the management of syncope
}

\author{
S Ahmad, M W Beckett
}

Emerg Med J 2004;21:e3 (http://www.emjonline.com/cgi/content/full/21/2/e3). doi: 10.1136/emj.2003.008870

See end of article for authors' affiliations

.....................

Correspondence to: DrM Beckett, Accident and Emergency Department, West Middlesex University Hospital, Isleworth,

Twickenham TW7 6AF, UK; dishawe@aol.com

Accepted for publication 25 June 2003
Objective: A meta-analysis of studies of the usefulness of raised serum prolactin in diagnosing generalised tonic-clonic seizures (GTCS) in patients presenting to the accident and emergency (A\&E) department after a single episode of syncope.

Methods: A three part question was defined. Medline, EMBASE, PubMed, the Cochrane Library were searched to identify relevant studies. Studies were evaluated for eligibility and quality and data extracted to calculate sensitivity (SN), specificity (SP), and likelihood ratios (LR).

Results: Of 13 relevant studies only three met the criteria for evaluation. If a serum prolactin concentration is greater than three times the baseline when taken within one hour of syncope, then in the absence of test "modifiers": (1) the patient is nine times more likely to have suffered a GTCS as compared with a pseudoseizure positive $\mathrm{LR}=8.92(95 \% \mathrm{Cl}(1.31$ to 60.91$)), \mathrm{SN}=0.62(95 \% \mathrm{Cl}(0.40$ to 0.83$)), \mathrm{SP}=0.89$ $(95 \% \mathrm{Cl}(0.60$ to 0.98$))$ and (2) five times more likely to have suffered a GTCS as compared with nonconvulsive syncope positive LR 4.60 (95\% Cl (1.25 to 16.90)), SN=0.71 (95\% Cl (0.49 to 0.87)), $\mathrm{SP}=0.85(95 \% \mathrm{Cl}(0.55$ to 0.98$))$.

Conclusion: A positive test result is highly predictive of a GTCS, however a negative test result does not necessarily exclude a seizure. Serum prolactin should be measured in patients presenting to the A\&E department within an hour of a syncopal episode, unless the cause is immediately obvious.
A 24 year old patient suffers a single episode of syncope. Clinical evaluation reveals no obvious cause or important sequelae. Is a serum prolactin concentration useful in excluding a seizure disorder?

\section{BACKGROUND}

Transient loss of consciousness is a common and diagnostically challenging problem for the emergency physician. The clinical picture may be suggestive of a genuine seizure disorder or syncope. Syncope as a presenting complaint accounts for up to $3 \%$ of emergency department visits and up to $6 \%$ of acute medical admissions. ${ }^{1}$ Even after extensive investigation, up to $41 \%$ of patients may not have a cause identified. ${ }^{2}$ This is likely to reflect the transient nature of the phenomenon, the complex underlying pathophysiological mechanisms involved, and overlap of acute neurology, cardiology, and psychiatric disciplines (see table 1).

The goal of the emergency physician, after exclusion of a life threatening condition, is to decide whether inpatient or outpatient management is warranted based on subsequent risk of mortality and morbidity. Accurate early diagnosis of a true seizure disorder will facilitate appropriate disposal and enable important future decisions to be made regarding medical management, work, and driving.

Often there is little history and with few objective clinical signs, establishing a working diagnosis in the A\&E department can be difficult. Furthermore, clinical evaluation and routine investigation in the $\mathrm{A} \& \mathrm{E}$ department may be inadequately sensitive to separate seizure from syncope. A diagnostic accuracy of $45 \%$ has been suggested using history and examination alone in predicting the cause of syncope. ${ }^{2}$ Electroencephalography and tilt testing for example may eventually be required to make a definitive diagnosis. In 1978 a raised serum prolactin concentration was found to be a useful marker of a generalised tonic clonic event if measured within an hour of the event. ${ }^{3}$ Since then its use as a biochemical diagnostic test after a true convulsive episode, pseudoseizure, and non-convulsive syncope has been subject to much interesting debate.
This study seeks to investigate the following: In patients presenting with syncope does a serum prolactin concentration of greater than three times the baseline accurately predict the occurrence of a GTCS?

\section{PHYSIOLOGY OF PROLACTIN SECRETION}

Human prolactin is synthesised by the anterior pituitary, secreted in an episodic manner, and is unique in that it is under tonic hypothalamic inhibition by dopamine (prolactin inhibiting factor). Circadian fluctuations occur with peak levels during the middle to end of the night with little change during the waking state.

Physiological causes of hyperprolactinaemia include pregnancy, lactation, sexual arousal, and stress. Destructive lesions of the hypothalamus, pituitary tumours (prolactinoma), and use of dopamine antagonists (phenothiazines, methyldopa, and morphine) also raise serum prolactin. Dopamine agonists lower serum prolactin (bromocriptine, L-dopa, and apomorphine). Baseline adult concentrations are up to $20 \mathrm{ng} / \mathrm{ml}$ in the non-pregnant woman and $10 \mathrm{ng} / \mathrm{ml}$ in adult men with a plasma half life of about 20 minutes. ${ }^{4}$

Table 1 Causes of syncope*

\begin{tabular}{ll}
\hline Cause & Mean prevalence (range)\% \\
\hline $\begin{array}{ll}\text { Neurally mediated syncope } \\
\text { vasovagal episode }\end{array}$ & $18(8-37)$ \\
situational syncope & $5(1-8)$ \\
carotid sinus syncope & $1(0-4)$ \\
Psychiatric disorders & $2(1-7)$ \\
Orthostatic hypotension & $8(4-10)$ \\
Medications & $3(1-7)$ \\
Neurological disease & $10(3-32)$ \\
Cardiac syncope & $4(1-8)$ \\
$\quad$ organic heart disease & $14(4-38)$ \\
arrhythmias & $34(13-41)$ \\
Unknown &
\end{tabular}


Table 2 Framework for considering study quality and likelihood of bias ${ }^{6}$

\begin{tabular}{ll}
\hline Study feature & Qualities sought \\
\hline Sample of patients & $\begin{array}{l}\text { Consecutive or randomly selected sample, recruited as a single cohort unclassified by } \\
\text { disease state, recruited from clinical setting and point in referral process where test would } \\
\text { be used, selection and referral process fully described, clinical and demographic } \\
\text { characteristics fully described. }\end{array}$ \\
Reference diagnosis & $\begin{array}{l}\text { Method and tests described in detail, positive and negative diagnoses clearly described, } \\
\text { diagnosis likely to be close to truth, available for all patients based on same tests and } \\
\text { information in all patients. Blinding procedures used to prevent knowledge of result of } \\
\text { experimental test influencing the reference diagnosis, made before treatment started. }\end{array}$ \\
Experimental test & $\begin{array}{l}\text { Application of test described in detail, positive and negative test results clearly described, } \\
\text { blinding procedures used to ensure that test is undertaken without knowledge of reference } \\
\text { diagnosis, test undertaken before treatment started, results reported for all patients, } \\
\text { including those with "grey zone" results, "gold standard" test in all patients (EEG, or } \\
\text { detailed description of clinical criteria where EEG not undertaken) }\end{array}$
\end{tabular}

Units are expressed as micro international units per litre $(\mathrm{miu} / \mathrm{l})$ or as nanograms per millilitre $(1 \mathrm{ng} / \mathrm{ml}=21.2 \mathrm{miu} / \mathrm{l})$. Electrochemical stimulation of the medial basal hypothalamus in animal models increases prolactin release. It is thought that in epilepsy, abnormal electrical activity leads to a suppression of dopamine (synthesised in the arcuate and periventricular nuclei of the medial basal hypothalamus) resulting in a raised serum prolactin. ${ }^{5}$

\section{METHODS}

\section{Search strategy}

Medline (1966 to Jan 2003) and EMBASE ( 1982 to Jan 2003) were searched using the Ovid interface and the following keywords: [ $\left\{\left({ }^{*}\right.\right.$ serum prolactin/ or prolactin.mp. or serum prolactin level/di) AND (generalised tonic clonic seizure or seizure disorder or seizure or fit\$).mp. OR (pseudoseizure or hysteria or hysterical fit).mp. OR (syncope or non convulsive syncope or syncopal attack).mp.\} LIMIT to (human and english language)]. The Cochrane Library, Pubmed, and key journals relating to emergency medicine were searched using the same search string in addition to a manual review of bibliographies of identified articles.

\section{Study selection}

A framework was used for considering study quality and likelihood of bias. ${ }^{6}$ (See table 2). Study features included the patient sample, reference diagnosis, and the experimental test itself.

\section{Data extraction}

Meta-analysis of studies of diagnostic accuracy is a two stage process. Stage 1 involved derivation of summary statistics for each study-that is, determining the sensitivity (SN), specificity (SP), and likelihood ratios (+LR, -LR). Stage 2 involved calculation of the pooled estimate of the SN, SP, and likelihood ratios. Data analysis and confidence intervals were calculated using CIA (confidence interval analysis) software ${ }^{7}$ and with reference to Sackett et al. ${ }^{8}$

Table 3 Studies of serum prolactin in GTCS and pseudoseizure disorder. Studies meeting criteria for evaluation

\begin{tabular}{|c|c|c|c|c|c|}
\hline & Study & Sample (total patients) & Reference diagnosis & Experimental test criteria & Comments \\
\hline 9 & Pritchard 1985 & 12 & Pseudoseizure & (PRL) $\vee 3$ baseline & $\begin{array}{l}\text { Tertiary neurology centre cohort, } 10 \text { of } 12 \\
\text { received gold standard test (video EEG), } 4 \\
\text { of } 6 \text { in seizure group were non-convulsive }\end{array}$ \\
\hline 10 & Collins 1983 & 35 & Pseudoseizure & (PRL) $\vee 3$ baseline & $\begin{array}{l}\text { EEG monitoring, tertiary neurology centre } \\
\text { cohort, no baseline values }\end{array}$ \\
\hline 11 & Alving 1998 & 58 & Pseudoseizure & $(\mathrm{PRL}) \vee 3$ baseline & $\begin{array}{l}\text { Video EEG in } 47 \text { of } 58 \text {, tertiary centre } \\
\text { cohort, individual patient data not } \\
\text { provided, baseline values taken too early }\end{array}$ \\
\hline 3 & Trimble 1978 & 14 & Pseudoseizure & (PRL) $\vee 3$ baseline & $\begin{array}{l}\text { No video EEG in pseudoseizure cohort, } \\
\text { pseudoseizure diagnosis made clinically } \\
\text { tertiary centre cohort }\end{array}$ \\
\hline 12 & Mehta 1994 & 69 & Pseudoseizure & (PRL) v3 baseline & $\begin{array}{l}\text { All patients had EEG, acute medical } \\
\text { inpatient cohort, baseline values in only } \\
\text { eight patients, individual patient data not } \\
\text { supplied }\end{array}$ \\
\hline 13 & Laxer 1985 & 51 & Pseudoseizure & $(P R L) \vee 3$ baseline & Tertiary centre, all had video EEG \\
\hline 14 & Hoppener 1982 & 18 & Pseudoseizure & (PRL) $\vee 3$ baseline & $\begin{array}{l}\text { Tertiary centre, none had EEG, timing of } \\
\text { baseline values uncertain. }\end{array}$ \\
\hline 15 & Rao 1989 & 11 & Pseudoseizure & (PRL) $\vee 3$ baseline & $\begin{array}{l}\text { Tertiary centre, all had video EEG, } \\
\text { individual patient data and baseline } \\
\text { values unavailable for comparison, type of } \\
\text { seizure unclear }\end{array}$ \\
\hline 16 & Abbott 1980 & 9 & $\begin{array}{l}\text { Healthy volunteers } \\
\text { simulating GTCS }\end{array}$ & (PRL) $\vee 3$ baseline & $\begin{array}{l}\text { Tertiary centre, none had EEG, no } \\
\text { baseline value in pseudoseizure group }\end{array}$ \\
\hline 16 & Abbott 1980 & 52 & $\begin{array}{l}\text { Age and sex matched } \\
\text { controls in A\&E department, } \\
\text { none with seizure }\end{array}$ & (PRL) $\vee 3$ baseline & $\begin{array}{l}\text { Accident and emergency department } \\
\text { cohort }\end{array}$ \\
\hline 17 & Fisher 1991 & 8 & Pseudoseizure & (PRL) $\vee 3$ baseline & $\begin{array}{l}\text { Tertiary centre, all underwent video EEG, } \\
\text { no baseline values. }\end{array}$ \\
\hline
\end{tabular}


Table 4 Studies of serum prolactin in syncope. Studies included in analysis

\begin{tabular}{|c|c|c|c|c|c|}
\hline & Study & $\begin{array}{l}\text { Sample (total } \\
\text { patients) }\end{array}$ & $\begin{array}{l}\text { Reference } \\
\text { diagnosis }\end{array}$ & $\begin{array}{l}\text { Experimental } \\
\text { test criteria }\end{array}$ & Comments \\
\hline 18 & Anzola 1993 & 37 & $\begin{array}{l}\text { GTCS v non- } \\
\text { convulsive non- } \\
\text { cardiac syncope }\end{array}$ & $\begin{array}{l}\text { (PRL) v } 3 \\
\text { baseline }\end{array}$ & $\begin{array}{l}\text { Tertiary centre cohort of patients } \\
\text { with transient loss of } \\
\text { consciousness. "Syncopal" } \\
\text { patients = EEG, cardiac and } \\
\text { autonomic tests }\end{array}$ \\
\hline 19 & $\begin{array}{l}\text { Pohlmann-Eden } \\
1993\end{array}$ & 95 & $\begin{array}{l}\text { GTCS } v \text { non-GTCS } \\
\text { (syncope, } \\
\text { hypoglycaemic } \\
\text { episode, TIAs, } \\
\text { pseudoseizure) }\end{array}$ & $\begin{array}{l}\text { [PRL] } \vee 3 \\
\text { baseline }\end{array}$ & $\begin{array}{l}\text { Tertiary centre cohort, multiple } \\
\text { alternative reference diagnoses } \\
\text { without EEG or description of } \\
\text { criteria for diagnosis }\end{array}$ \\
\hline
\end{tabular}

\section{RESULTS}

Thirteen relevant studies were identified in the search. Only three met the criteria required for diagnostic test assessment. (See comments, table 3 and 4). Serum prolactin appears to be released at the onset of a GTCS reaching a peak increase at 15-25 minutes. ${ }^{3}$ Values remain significantly increased up to one hour after cessation of fit. ${ }^{9} 10^{16}{ }^{20}$ In the evaluation of the "first fit" patient, a baseline pre-ictal value is likely to be unavailable. Recovery prolactin values 24 hours or more after the seizure closely resemble those in control non-stressed subjects and hence provide an acceptable measure of the baseline value for these patients. ${ }^{21}$ In the diagnosis of a GTCS video EEG is the accepted gold standard. Tables 5 and 6 summarise diagnostic yield of serum prolactin in differentiating a GTCS from pseudoseizure and syncope.

\section{DISCUSSION}

\section{Modifiers of the test}

\section{Alcohol and medication}

Seizures associated with alcohol withdrawal show a rise in serum prolactin to values similar to those seen with other causes of GTCS. $^{20}$ People with epilepsy stabilised with phenytoin seem to have higher baseline values than nonmedicated epileptic subjects. ${ }^{22}$ Diazepam, commonly used to terminate a seizure does not affect serum prolactin values. ${ }^{23}$ There are no data relevant to newer anti-epileptic medications, SSRIs, and HRT influence on serum prolactin.

\section{Stress, temperature, and children}

Patients presenting with stressful acute medical conditions, which are non-seizure related, for example acute unstable angina, asthma attack, and acute abdomen show modestly raised serum prolactin values when compared with healthy subjects on arrival to the A\&E department, which do not appear to rise over a 60 minute period. ${ }^{21}$ In children normal values are less than $17 \mathrm{ng} / \mathrm{ml}$ for $0-1$ years and less than $9.4 \mathrm{ng} / \mathrm{ml}$ for 2-14 years, with slightly higher values in girls than boys. Temperature by itself does not account for a rise in serum prolactin, and values are therefore normal in febrile children. After a febrile seizure, patients' show similar rises to non-febrile seizure patients, thus "fit" regardless of fever will result in raised prolactin values. ${ }^{24}$

\section{Validity of the evidence}

Patients in two of the studies ${ }^{13} 18$ evaluated underwent the diagnostic test in question and the reference gold standard (EEG). In the third study ${ }^{3}$ the clinical criteria were thought acceptable for defining the "non-target" disorder pseudoseizure group. All studies involved a tertiary care cohort, which may have introduced selection bias, a representative sample would have been a prospective A\&E department cohort. The three studies included evaluated patients with the target disorder and disorders commonly confused with the target disorder of interest-that is, pseudoseizure and non-convulsive syncope at a point in the clinical process where the test could conceivably be used. All studies suffered from small sample sizes reflected in the wide confidence intervals.

\section{Clinical application of the test}

In the absence of a reliable baseline value, a one off serum prolactin value is unlikely to affect decision making in the A\&E department. Patients, however, often suffer months of uncertainty while being investigated for "blackouts" and by

Table 5 Estimates of two eligible studies of diagnostic accuracy of serum prolactin concentration (three times the baseline within one hour of collapse) in detecting GTCS from pseudoseizure

\begin{tabular}{|c|c|c|c|c|c|}
\hline \multicolumn{3}{|l|}{ Sensitivity } & \multicolumn{3}{|l|}{ Specificity } \\
\hline Study & $\begin{array}{l}\text { (true positives }+ \text { false } \\
\text { negatives) }\end{array}$ & Sensitivity & Study & $\begin{array}{l}\text { (false positives }+ \\
\text { true negatives) }\end{array}$ & Specificity \\
\hline \multirow{3}{*}{$\begin{array}{l}3 \text { Trimble } \\
1978 \\
13 \text { Laxer } \\
1985\end{array}$} & $4 / 8$ & $50 \%$ & 3 Trimble 1978 & $5 / 6$ & $83 \%$ \\
\hline & $23 / 31$ & $74 \%$ & 13 Laxer 1985 & $19 / 20$ & $95 \%$ \\
\hline & \multicolumn{3}{|c|}{$\begin{array}{l}\text { Pooled estimate of } \mathrm{SN}=0.62 \text { (95\% Cl }(0.40 \\
\text { to } 0.83) \text { ) } \\
\text { Pooled +ve likelihood ratio = } 8.92 \text { (1.31 to } \\
60.91) \text { (Lr+ve }>5 \text {, strong diagnostic } \\
\text { evidence) } \\
\text { Post-test probability = 93\% chance of a GTCS } \\
\text { if test positive (RULE IN DIAGNOSIS of } \\
\text { GTCS) }\end{array}$} & \multicolumn{2}{|c|}{$\begin{array}{l}\text { Pooled estimate of SP }=0.89(95 \% \mathrm{Cl} \\
(0.60 \text { to } 0.98)) \\
\text { Pooled }- \text { ve likelihood ratio }=0.44 \\
(0.22 \text { to } 0.91) \text { (Lr-ve } \\
<0.1=\text { convincing evidence) } \\
\text { Post-test probability = } 39 \% \text { chance of } \\
\text { GTCS event if test negative (RULE OUT } \\
\text { DIAGNOSIS of GTCS) }\end{array}$} \\
\hline
\end{tabular}


Table 6 Estimates of one eligible study of sensitivity and specificity of serum prolactin value (three times baseline within one hour of collapse) in detecting GTCS from noncardiac non-convulsive syncope

\begin{tabular}{|c|c|c|c|c|c|}
\hline \multicolumn{3}{|c|}{ Sensitivity } & \multicolumn{3}{|l|}{ Specificity } \\
\hline Study & $\begin{array}{l}\text { (true positives + false } \\
\text { negatives) }\end{array}$ & Sensitivity & Study & $\begin{array}{l}\text { (false positives + true } \\
\text { negatives) }\end{array}$ & Specificity \\
\hline \multirow{2}{*}{$\begin{array}{l}18 \\
\text { Anzola } \\
1993\end{array}$} & $17 / 24$ & $71 \%$ & $\begin{array}{l}18 \text { Anzola } \\
1993\end{array}$ & $11 / 13$ & $85 \%$ \\
\hline & \multicolumn{3}{|c|}{$\begin{array}{l}\mathrm{SN}=0.71(95 \% \mathrm{Cl}(0.49 \text { to } 0.87)) \\
\text { +ve Likelihood ratio }=4.60 \text { ( } 1.25 \text { to } 16.90) \\
\text { (Lr+ve }>5 \text {, strong diagnostic evidence) } \\
\text { Post-test probability }=90 \% \text { chance of a GTCS } \\
\text { if test positive (RULE IN DIAGNOSIS of GTCS) }\end{array}$} & \multicolumn{2}{|c|}{$\begin{array}{l}\mathrm{SP}=0.85(95 \% \mathrm{Cl}(0.55 \text { to } 0.98)) \\
\text {-ve Likelihood ratio }=0.35(0.18 \text { to } 0.67) \\
\text { (Lr-ve }<0.1=\text { convincing evidence) } \\
\text { Post-test probability }=39 \% \text { chance of GTCS } \\
\text { event if test negative (RULE OUT DIAGNOSIS } \\
\text { of GTCS) }\end{array}$} \\
\hline
\end{tabular}

taking advantage of the time in the A\&E department a sensible prediction can be made as to the presence of a GTCS. Serum prolactin should therefore aid management in the neurology clinic and give the patient the benefit of an earlier diagnosis and perhaps enable earlier start of effective treatment. Furthermore, appropriate interpretation of a post-syncopal value against baseline patient value should avoid a false negative risk and potential for labelling the patient with pseudoseizure.

The turn around time in the A\&E department is about one to two hours for a serum prolactin result, similar to that of routine biochemistry. This takes into account the time taken for sampling, transport to the laboratory, centrifugation, booking, and analysis using an Architect (Abbott Laboratories) automated immunoassay analyser at a cost of £5 per sample (personal communication with chief MLSO Northwick Park Hospital). Knowledge of other characteristics of a particular patient affecting their prior probability of GTCS in combination with serum prolactin as part of a diagnostic algorithm should increase the diagnostic accuracy.

The potential of a false positive risk is theoretically possible with patients being inappropriately labelled as "epileptic". For this reason it is important to emphasise the test result gives a risk and not a disease state.

This study has looked at an arbitrary cut off value of three times the baseline value. The predictive value of a threshold effect has not yet been established.

\section{Suggested improvements}

Future studies comparing several diagnostic tests, for example, serum creatinine phosphokinase, serum lactate, or a testing algorithm (in combination with clinical, biochemical and brain imaging studies) in properly designed comparative studies in a prospective emergency department cohort are required to investigate the negative predictive value of serum prolactin.

\section{Practice points}

- When differentiating seizure from other causes of transient loss of consciousness serum prolactin values taken within one hour of the event can be useful

- Always consider physiological, pathological, and iatrogenic causes of raised serum prolactin when interpreting results

- A baseline comparison value should be taken, seizure free at a similar time of day, 24 hours later

\section{CONCLUSIONS}

A 24 year old patient suffers a single episode of syncope. Clinical evaluation reveals no obvious cause or important sequelae. Is a serum prolactin concentration useful in excluding a seizure disorder?

- In the absence of pregnancy, lactation, and the use of dopamine antagonistic drugs, a level three times the baseline is highly specific for a convulsive event if taken within one hour after cessation of the syncopal episode.

- A negative result does not exclude a syncopal episode secondary to a GTCS.

- Raised values seem to be independent of aetiology of GTCS.

\section{RECOMMENDATIONS}

- A\&E department physicians should measure the serum prolactin to facilitate eventual diagnosis and medical management.

- Further research is required ideally in a large prospective A\&E department cohort of patients presenting with syncope to fully demonstrate the potential of serum prolactin measurement

\section{Contributors}

SA carried out the literature search, collected, processed and analysed the data, and wrote the paper. MB initiated the original idea and edited the paper. SA acts as guarantor.

\section{Authors' affiliations}

S Ahmad, Paediatric Accident and Emergency Department, Queen Elizabeth Central Hospital, Blantyre, Malawi

M W Beckett, Accident and Emergency Department, West Middlesex University Hospital, Isleworth, Twickenham, UK

Funding: none.

Competing interests: none declared.

\section{REFERENCES}

1 Kapoor WN. Evaluation and management of the patient with syncope. JAMA 1992; 18:25-53.

2 Kapoor WN. Syncope. N Engl J Med 2000;343:1856-62

3 Trimble M. Serum prolactin in epilepsy and hysteria. BMJ 1978;2:1682

4 Thorner MO. Endocrine disorders. In: Weatherall DJ, Ledingham JGG, Warrell DA, eds. Oxford textbook of medicine. Oxford: Oxford University Press, 1996:1576.

5 Clemens JA, Shaar CJ, Kleber JW, et al. Reciprocal control by the preoptic area of $\mathrm{LH}$ and prolactin. Exp Brain Res 1971;12:250-3.

6 Deeks JJ. Systematic reviews of evaluations of diagnostic and screening tests. BMJ 2001;323:157-62.

7 Altman DG, Machin D, Bryant TN, et al. Statistics with confidence, 2nd edn. London: BMJ Publishing Group, 2000. 
8 Sackett DL, Straus SE, Richardson WS, et al. Evidence based medicine, how to practice and teach EBM. 2nd edn. Livingstone: Churchill, 2000.

9 Pritchard PB, Wannamaker BB, Sagel J, et al. Serum prolactin and cortisol levels in evaluation of pseudoepileptic seizures. Ann Neurol 1985;18:87-9.

10 Collins WCJ, Lanigan O, Callaghan N. Plasma prolactin concentrations following epileptic and pseudoseizures. J Neurol Neurosurg Psychiatry 1983;46:505-8

11 Alving J. Serum prolactin levels are elevated also after pseudo epileptic seizures. Seizure 1998;7:85-9.

12 Mehta SR, Dham SK, Lazar Al, et al. Prolactin and cortisol levels in seizure disorders. J Assoc Physicians India 1994;42:709-12.

13 Laxer KD, Mullooly, Howell B. Prolactin changes after seizures classified by EEG monitoring. Neurology 1985;35:31-5.

14 Hoppener RJ, Rentmeester TH, Arnoldussen. Changes in serum prolactin levels following partial and generalised seizures. Br J Clin Pract 1982; 18(suppl):193-5.

15 Rao ML, Hermann S, Jurgen B. Epileptic but not psychogenic seizures are accompanied by simultaneous elevation of serum pituitary hormones and cortisol levels. Neuroendocrinology 1989;49:33-9.

16 Abbott RJ, Browning M, Davidson DLW. Serum prolactin and cortisol concentrations after grand mal seizures. J Neurol Neurosurg Psychiatry 1980;43:163-7.
17 Fisher RS, Chan DW, Bare M, et al. Capillary prolactin measurement for diagnosis of seizures. Ann Neurol 1991;29:187-90.

18 Anzola GP. Predictivity of plasma prolactin levels in differentiating epilepsy from pseudoseizures: a prospective study. Epilepsia 1993;34:1044-8.

19 Pohlmann-Eden B, Wellhauser H, Stefanou A, et al. Correlation of serum prolactin and cortisol values with paroxysmal disorders of epileptic and nonepileptic origin and their clinical value. Fortschr Neurol Psychiatr 1993;61:363-8.

20 Aminoff MJ, Simon RP, Wiedemann E. The hormonal responses to generalised tonic-clonic seizures. Brain 1984;107:569-78.

21 Culebras A, Miller M, Bertram L, et al. Differential response of growth hormone, cortisol, and prolactin to seizures and to stress. Epilepsia 1987;28:564-70.

22 Elwes RDC, Dellaportas C, Reynolds EH, et al. Prolactin and growth hormone dynamics in epileptic patients receiving phenytoin. Clin Endocrinol (Oxf) 1985;23:263-70

23 Wilson JD, King DJ, Sheridan B. Tranquilisers and plasma prolactin. BMJ 1979;1:123-4.

24 Joel AF, Lavelle J, Clancy R. Using age appropriate prolactin levels to diagnose children with seizures in the emergency department. Acad Emerg Med 1997;4:202-5. 